\title{
Introduction to Kris, a traditional weapon of Indonesia: Preserved-lingering issues of facts
}

\author{
1Sugeng Purwanto, IIdha Nurhamidah* \\ ${ }^{1}$ English Literature Study Program, Faculty of Language and Cultural Studies, \\ Universitas Stikubank, Semarang, Indonesia \\ ${ }^{2}$ Engllish Literature, Language and Communication Science Faculty, Universitas Islam \\ Sultan Agung, Semarang, Indonesia
}

*Corresponding Author

Email: idhanurhamidah@unissula.ac.id

Received:

28 May 2020
Revised:

18 June 2021
Accepted:

29 July 2021
Published:

31 August 2021

\begin{abstract}
The current article examined some issues on Kris, a traditional weapon of Indonesia as a high cultural heritage, which is up to now still preserved with all of its manifestations. A Kris may be viewed from its definition, magical charms, parts, elements, maintenance, symbolic values, philosophical meanings, production periods and legendary preservation. Ethnolinguistic investigation revealed that Kris has significantly contributed to the lexical domain, hereinafter referred to as Kris Registers. There are a lot of registers related to its entity, which are of great difficulty for lay people to understand, except those who are really involved in the world of Kris, such as Kris masters (makers), parapsychologist, antiques collectors, cultural researchers to mention only a few. A cultural fact has been identified-that it is the owners' ways of life in addition to their personal characteristics. One important recommendation of Kris with its all manifestations is that it has to be preserved as an asset of high cultural values through one person one Kris program.
\end{abstract}

Keywords: Kris; cultural heritage; symbolic values; philosophical meanings; ways of life

\section{INTRODUCTION}

The development of culture and human civilization has been of high dynamics. Findings on human civilization reported in ethnographic studies showed its rapidness and unpredictability-simply for survival purposes (Coenen et al., 2021; Peng \& Deng, 2021; Wu et al., 2021). With respect to weapons, for example, people of the former generation were historically recorded as using kris (daggers), spears, javelins, arrows, each of which to kill or injure animal hunts or even among human-beings in contestation of power, wealth, and women (Erdal \& Gucuyener, 2021; Pidada, 2021).

In the old ages, historically speaking, it was all about "Warangan", a kind of poison, polished onto the weapons of whatever types. In this respect, the more deadly poisons were, the better they would be for the weapons to kill or 
Purwanto, S., \& Nuhamidah, I. (2021). Introduction to Kris, a traditional weapon of Indonesia:

injure hunts or enemies (Rukachaisirikul et al., 2021; van Huis, 2021; Zvejniece et al., 2021). Therefore, in fighting between tribes for example each of them was extremely careful not to be scratched by even the slightest injury as it might lead to the death due to the danger of the poison. It was very likely that a small scratch might provide chances for poison to spread throughout the whole body. It is important to note that warangan producers with various levels of malignancy, usually also produce an antidote to help treat or cure the victims.

In terms of etymological definition, Kris (Groneman, 2009) (originally

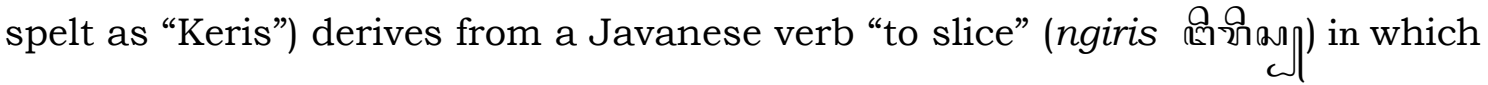
the word Keris has three Javanese level of politeness. In its highest form of politeness (Krama Inggil) it is called Wangkingan. In medium politeness (Krama Madya), it is called Duwung, and the word Keris itself belongs to the lowest Javanese linguistic politeness (Ngoko). However, several words referring to Keris do exist in other local languages in Indonesia, such as Karih in Minangkabau, and Sele in Buginese and Makassar. Other Asian languages also have words referring to Kris, such as Kalis in Tagalog despite its form of Kalis is more "sword" than "dagger", Kris or Krit in Thai, Kareh in Yala dialect, Kris in Khmer. Some other European spelling for Kris includes "cryse", "crise", "criss", "kriss" and "creese". English maintains its spelling of Kris for Keris.

Lexical definition of Kris is a kind of dagger used as a close-range stabbing tool despite the fact that its use has evolved in line with the development of human civilization in which modern civilization has noted that Kris is used as an ornament for traditional costumes (outfits) and traditional ceremonies (Julianto et al., 2021). However, some Indonesian (and Malaysian) people still consider Kris as a sanctified heirloom with supranatural power for wealth, strength, charism, love charms and the like (Aji et al., 2019).

\section{Previous Studies}

With respect to previous studies on kris, some culturalists have conducted researches with different focuses. From aesthetics, kris is considered as a work of arts with high heritage of Indonesia (Fatmawati, 2021). Kris has also been researched in terms of supranatural power, resulting in the facts that kris has a special energy depending on the patterns of metal alloy decoration (Pamor) on the blade (Bilah), designs of blade (Dhapur) and Tangguh-period of production. In terms of the process of Kris production, a Kris is made by a special master/blade smith (Empu) employing the so-called folding-forging techniques with high complexity in each phase. To this end, the novelty of this article is that we, the authors, ethnolinguistically, investigated Kris comprehensively regarding the aesthetics, physical forms, magical values and production processes to come up with lexical registers of Kris for public knowledge at international level with the following research questions:

(1) What are the names of kris blades (Wilah) and the philosophies related to them?

(2) What are the names of the hilts or handles (Hulu) of kris and the philosophies related to them?

(3) What are the names of the sheaths (Werangka) of kris and the philosophies related to them? 
(4) What are the names of the patterns (Pamor) of kris and the philosophies related to them?

(5) What are the materials and processes that are required in the production of Kris?

(6) What are the magical powers of particularly selected legendary Kris?

The answers to the above research questions are urgently required to highlight Kris as one of Indonesia's masterpieces in the Oral and Intangible Heritage of Humanity (OIHH) proclaimed by UNESCO since 2005 (Sutrisno, 2018).

\section{METHOD}

This study employed ethnolinguistic method by retrieving comprehensive information from various resources, such as outlined below (respondents) and other documents regarding the research object (kris)

\section{Respondents}

By respondents, we mean seven public figures with expertise in kris, such as collectors, paranormal, and culturalists. Semi closed interviews were held to find out information according to their expertise. However, as requested to protect the respondents' privacy, names and other details were not made public.

\section{Instruments}

Methodologically speaking, we, the researchers, acted as the instruments. We were aided by a super sensitive audio recording instrument in documenting the respondents' responses to the questions in a semi-structured interview kit, as another instrument.

\section{Procedures \\ Data Collection}

By appointment, we visited each public figure for an interview regarding the information related to $\mathrm{kris}$ as outlined in the research questions. All the interviews were recorded by means of super-sensitive audio recorder for validity purposes. Each interview lasted in approximately 45 minutes for each question. There were six questions in line with the research question. Each respondent (informant) as given freedom to choose any of the six questions which he thought, he could describe the issue(s) in detail. The interview questions are listed in the Appendix.

\section{Data analysis}

The collected data were identified, classified, analysed and interpreted of which the results were reported in a descriptive, qualitative and interpretative presentation to fulfil the current demands for comprehensive information around a traditional weapon (dagger) in all its variants and manifestations. However, due to the authors' constraints of time and expertise, the discussion is largely limited to the use of Kris in modern era in which the data from interviews were than descriptively narrated to present comprehensive information. 


\section{RESULTS AND DISCUSSION}

Presented below are the findings and discussion dealt with per Research Question to facilitate thorough comprehension of the subject matter. Information contained herein is the aggregated results of interviews with some public figures to tap down their thorough knowledge of Kris from philosophical, technological and mythological viewpoints. Their opinions may also be referred to related researches.

\section{The blade of Kris}

Basically, Kris has five parts, namely (1) Pesi, (2) Ganja, (3) Bongkot, (4) Wadhuk, and (5) Pucuk, each of which is elaborated from the interviews. Figures below were linked to their resources.

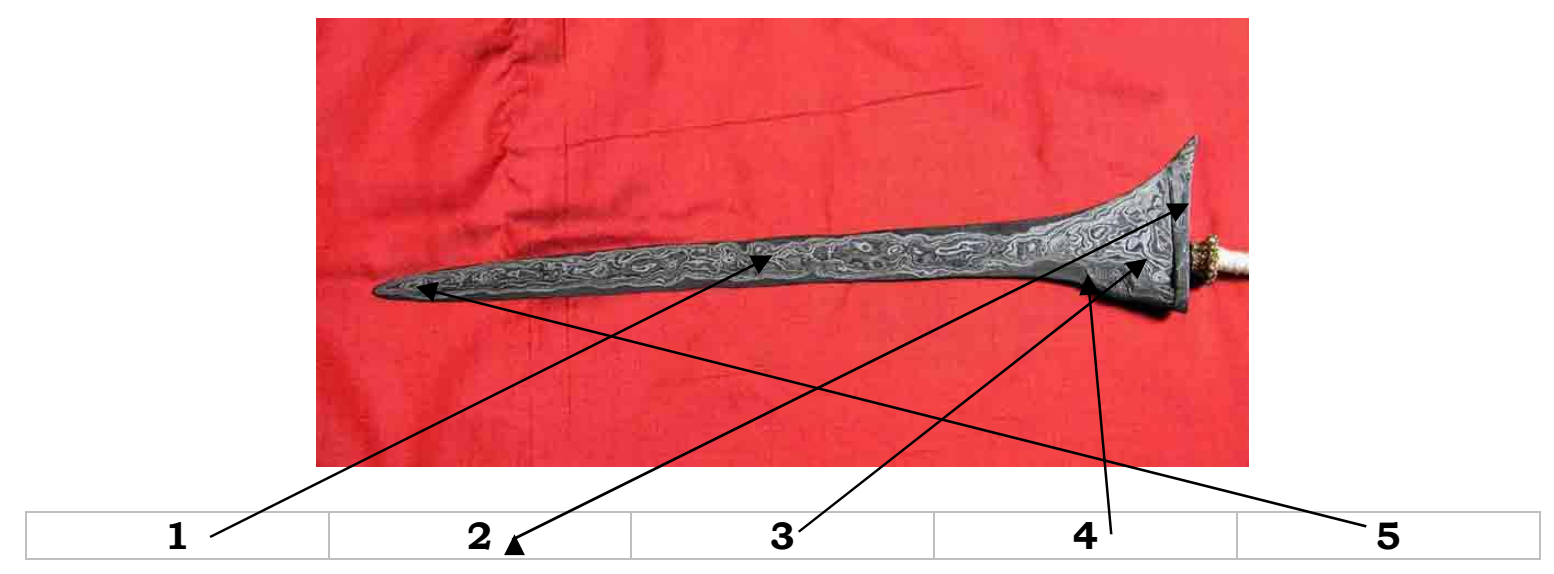

(1) Pesi

Figure1. Typical Straight Kris

Pesi or bilah is the principle blade of Kris. It will determine whether the Kris is straight or wavy (resembling a snake). It is usually narrow with a wide asymmetrical base. Although Kris measures differently, its length is between 15 to 50 centimetres, sharp on both edges and tip, broader and asymmetric shape near the hilt.

(2) Ganja

Ganja is attached to the Kris base (with a pointed end). It can be separated from the blade but may also be permanently attached, depending on the blade smith (empu).

(3) Bongkot

Bongkot is the Kris based as opposed to Pucuk (the tip). It is exactly to which the Ganja is attached.

(4) Wadhuk

Wadhuk is the Kris belly as opposed to back (rarely discussed) of a Kris below which a Kris may be ornamented with a figure of dragon or lion, as then being named "Naga Raja" (King Dragon) or "Singabarong" (Lion of Barong. Many are left untouched as shown in Figure 1. 


\section{(5) Pucuk}

Pucuk is the pointed tip of Kris on which (in the past) poisonous warangan is polished. Some are polished with poisonous warangan along the blades. Nowadays warangan is used to make the surface patterns (Pamor) physically emerge, as revealed in the interviews. follows:

More specifically a blade of Kris is illustrated in names of blade parts as

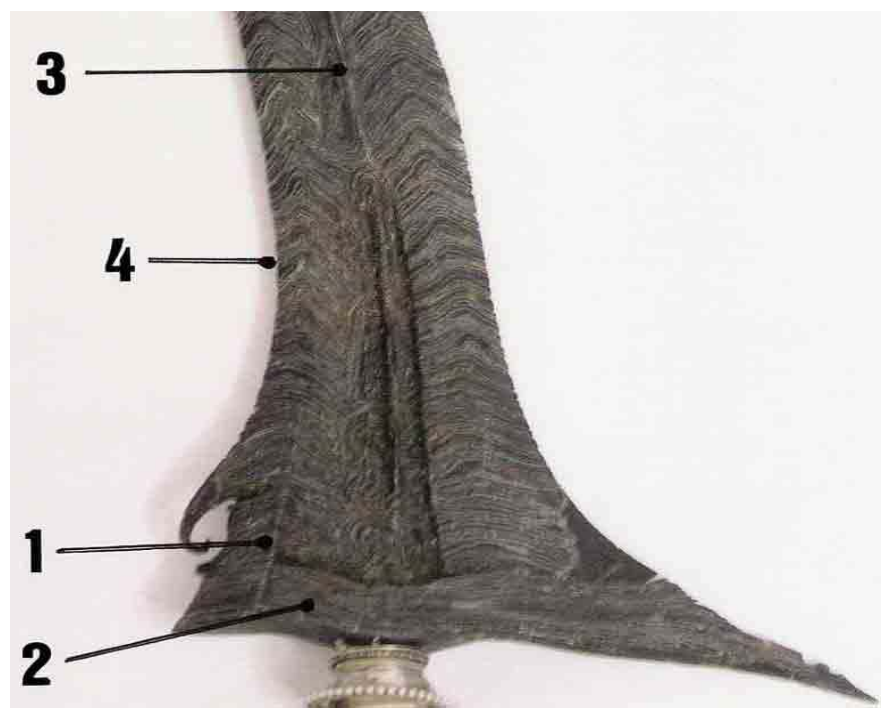

Figure 2. Blade in More Details

No (1) is called Gandik, (2) Ganja (3) Ada-ada, and (4) Lok 1 (curve 1) from which an individual may want to start counting the Lok. In wavy Kris, there are Kris of Lok 3 (3 curves), Lok 5 (5 curves). Traditionally, the highest Lok is Lok 13 where there are 13 curves from the base to the tip. A straight Kris has no Lok. In other words, Lok applies to wavy Kris (Frey, 2003).

Ada-ada is a visible line along the middle of the blade, extending from the base to the tip. Meanwhile, located on the top part of the Gandik is Kembang kacang, a protrusion shaped as an elephant's trunk, thereby sometimes being called telale gajah. There are several forms of Kembang kacang of which it is distinctively called Kembang kacang pogok as it looks like a snub nose (Wijayanto, 2019).

Some other parts of Kris blade are tabulated in Table 1 for ease of identification.

Table 1. Some Other Parts of Kris Blade

\begin{tabular}{rll}
\hline No & \multicolumn{1}{c}{ Name } & \multicolumn{1}{c}{ Location } \\
\hline $\mathbf{1}$ & Jenggot (beard) & $\begin{array}{l}\text { Spines and serrations carved on the top of Kembang } \\
\text { kacang }\end{array}$ \\
\hline $\mathbf{2}$ & $\begin{array}{l}\text { Lambe gajah } \\
\text { (elephant's lip) }\end{array}$ & $\begin{array}{l}\text { Some protrutions located in front of Gandik and } \\
\text { below Kembang kacang. (either single or double) }\end{array}$ \\
\hline $\mathbf{3}$ & Pejetan & A cavity located behind Gandik and just above Ganja \\
\hline $\mathbf{4}$ & Tikelalis & A channel located on the front side of the blade \\
\hline $\mathbf{5}$ & Sogokan & $\begin{array}{l}\text { Parallel blood grooves starting from the base of the } \\
\text { blade on either side from the middle line (Ada-ada) }\end{array}$ \\
\hline
\end{tabular}


Purwanto, S., \& Nuhamidah, I. (2021). Introduction to Kris, a traditional weapon of Indonesia: Preserved-lingering issues of facts. EduLite: Journal of English Education, Literature, and Culture, 6 (2), 397 410. http://dx.doi.org/10.30659/e.6.2.397-410

\begin{tabular}{|c|c|c|}
\hline 6 & Srawehan & A channel located behind the back of Sogokan \\
\hline 7 & Kruwingan & Two channels located on either side of Ada-ada \\
\hline 8 & Gusen & Flat face located between Kruwinan and Lislisan \\
\hline 9 & Greneng & $\begin{array}{l}\text { Serretions and spines carved on the rare side of } \\
\text { Ganja at the bottom of back face of blade }\end{array}$ \\
\hline 10 & Tingil & $\begin{array}{l}\text { A single sharp protrusion located on the back side of } \\
\text { Ganja }\end{array}$ \\
\hline 11 & Jalen & A small protrusion located in front of Gandik \\
\hline 12 & Jalu memet & A small protrusion located at the bottom of Gandik \\
\hline
\end{tabular}

The blade of Kris is either straight or wavy (like a snake). The (straight) Kris philosophically symbolizes 'determination' to maintain principles while the wavy Kris symbolizes 'wisdom' (strategically talented). However, the Lok (curve, wave) has only one goal (peak), and in this case 'God'. Everyone shall return to God. The symbolic meanings of the number of curves are presented in Table 2 below.

Table 2. Symbolic Meanings of Lok (Curves)

\begin{tabular}{ccl}
\hline No. & Lok & \multicolumn{1}{c}{ Symbolic Meaning } \\
\hline $\mathbf{1}$ & Lok 3 & $\begin{array}{l}\text { Sometimes called 'Jangkung' meaning 'supported', This refers to the } \\
\text { hope that the owner's goals will be supported by the mantra of the } \\
\text { blade smith (empu) }\end{array}$ \\
\hline $\mathbf{2}$ & Lok 5 & $\begin{array}{l}\text { Symbolizing political power, normally owned by a King, indicating } \\
\text { 'perfection' as the number of fingers, Islamic prayers (5 times) }\end{array}$ \\
\hline $\mathbf{3}$ & Lok 7 & $\begin{array}{l}\text { Symbolizing those who have completed their journey in this world, } \\
\text { and are ready for the world after; normally owned by a former King or } \\
\text { spiritual comforters. }\end{array}$ \\
\hline $\mathbf{4}$ & Lok 9 & $\begin{array}{l}\text { Symbolizing spiritual perfection; good for religious leaders, } \\
\text { consultants, professors. }\end{array}$ \\
\hline $\mathbf{5}$ & Lok 11 & $\begin{array}{l}\text { Good for love charms, playboys, indicating sewelas (welas=love), } \\
\text { appropriate for polygamous men. }\end{array}$ \\
\hline $\mathbf{6}$ & Lok 13 & $\begin{array}{l}\text { Good for power and protection, owned by managers, kings, any } \\
\text { leader }\end{array}$ \\
\hline
\end{tabular}

\section{Hilts or handles}

The handle (hilt, hulu) of Kris is very often carved in meticulous details, resembling various animals and Hindu Deities fthough it is less practiced since Islam was introducedt. It is usually made of precious materials such as fwood, gold, ivorył which at the same time increasesing the price of Kris. Bali Kris manufacturers often create handles in the form of demons coated in gold and adorned with precious stones, such as rubies. Normally precious materials for handles are negotiated with the power of Kris. A Kris for presidential souvenirs may be furnished with expensive materials.

The names of hilts designs among others include (1) Tunggak Semi (growth of base of cut trees (2) Putri Kinurung (curbed princess), from Surakarta, (3) Batara Guru (God's King) and (4) Pulasir (God's king) from Madura, (5) Punukan (lump) from Palembang, (6) Ratmaja from Bali, (7) Pulunan (luck) from Cirebon, (8) Pakaka (luck) from Pattani. Palembang and Sulawesi produce handles resembling seabirds (Rahman, 2020). 
EduLite Journal of English Education, Literature, and Culture

Vol. 6, No. 2, August 2021, pp. 397-410

E-ISSN: 2528-4479, P-ISSN: 2477-5304

http://jurnal.unissula.ac.id/index.php/edulite DOI: http://dx.doi.org/10.30659/e.6.2.397-410

With respect to philosophical symbolization, the name of the design may represent the intended meaning. Tunggak Semi (growth of base of cut trees), for instance, is a good for businessmen as it symbolizes growth. A romantic man or a tplayboył may want to own Kris with Putri Kinurung hilt as he may want to put women in his romantic jails. Meanwhile, those who want political power may want Kris with Batara Guru or Pulasir designs of hilts. Punukan hilts may be suitable for anyone who wants wealth. Palembang and Sulawesi Kris may be good for artists or public figures. Again, the designs of hilts must be appropriate with the intended power of the Kris.

\section{Sheath (Werangka)}

A kris cannot go without its sheath. It was as if the house of kris to keep the it, in a safe place, when not in use. Therefore, the noun 'sheath' can be verbalized, meaning that 'to sheath' is to put Kris into its resting place, and to un-sheath (unsheath) is to pull Kris out of its sheath. However, the current study does not deal with the rules for sheathing and unsheathing Kris.

Similar to the hilt, a kris' sheath (Werangka) is also an artistic object. It may be made from various kinds of materials, normally a wooden frame to hold the blade which can be coated with metals such as brass, iron, silver, or even gold, usually carved in sulur (swirl) or floral motifs. The upper part of the sheath formed a broad curved handle made from wood or possibly ivory. It could be decorated with precious or semi-precious stones. Therefore, it is hard to imagine how beautiful and costly is the Kris' sheath owned by the Sultan of Yogyakarta, for example. However, with respect to the philosophy of sheath, we failed to get the information. Therefore, we just assume that sheath serves as 'beauty' and 'pride' for the Kris owners.

\section{Surface Patterns (Pamor)}

Pamor is the essence of Kris. Not only does the pattern welding work demonstrate the blade smith (empu) but also characterize the power of Kris. Pamor, mixture of alloys, is generated by welding together wrought iron and nickel. Afterward, it is acidized to create a contract between the darkened iron and the brightened nickel. It is argued that the best Pamor is made from meteorite iron. However, due to scarcity of meteorite iron, only special Pamor of Kris (probably belonging to the Royal Family) may be made from real meteorite iron. Engineering in manufacture of Kris is always possible in line with the development of forging technology, namely the use of nickle.

According to the forging techniques, Pamor can be classified into two types, namely Pamor Mlumah (flat-horizontal) in which the laminating is parallel to the flat surface of the blade, and Pamor Miring (slanting) when the laminating is aligned to an angle to the flat surface of the blade. Meanwhile, according to the design (by the smiths), there are also two types of Pamor, namely Pamor Tiban which is accidently created (not as designed), and the other Pamor Rekan of which the patterns are really designed and controlled by the blade smith.

Pamor itself can be located on the Sorsoran (main part of the kris body). It can also be designed as Flowers (Flower Design), Pamor Tiban, Basic

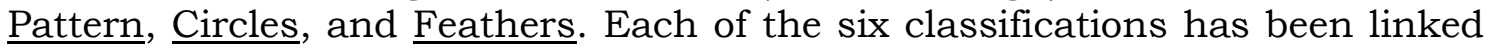
to further elaboration on the types of Pamor illustrated with pictures of each 
Purwanto, S., \& Nuhamidah, I. (2021). Introduction to Kris, a traditional weapon of Indonesia: Preserved-lingering issues of facts. EduLite: Journal of English Education, Literature, and Culture, 6 (2), 397 410. http://dx.doi.org/10.30659/e.6.2.397-410

Pamor, including the mystical functions. In short, the power of Kris is supported by its Lok (curve), hilt, and Pamor (Surface Patterns) of which the most significant is the Pamor (Handriyotopo \& Simatupang, 2018).

To give a general ..., Table 3 below displays some distinctive names of Pamor and their symbolic meanings

Table 3. Distinctive Pamor and their symbolic meanings

\begin{tabular}{clll}
\hline No & \multicolumn{1}{c}{ Design } & \multicolumn{1}{c}{ Name } & \multicolumn{1}{c}{ Symbolic Meanings (Philosophy) } \\
\hline 1 & On the Sorsoran, & Gumbala Geni & To prevent from bad conducts \\
\hline 2 & Flowers & Sekar Pala & To make the owner famous \\
\hline 3 & Pamor Tiban & Beras Wutah & To bring about luck and peaceful life \\
\hline 4 & Basic Patterns & Dadung Muntir & To increase authority, and bravery \\
\hline 5 & Circles & Udan Mas & To achieve wealthy life \\
\hline 6 & Feathers & Ronkenduru & To achieve power of leadership \\
\hline
\end{tabular}

Most importantly, when an individual wants to own a Kris, he or she can simply buy one or more than one upon consultation with the master (parapsychologist) to make sure that the Kris is appropriate otherwise it will be useless. In the mystical world, it is taboo to talk about purchases (beli) and sales (jual) of heirloom. Instead, the word memahari, or mahari applies to purchases, while maharkan applies to sales. Basically, these two words derive from one stem "mahar" (dowry), similar to a wedding transaction.

In purchase of Kris, according to an association of Kris collectors, called Puriwiji (sometimes traditionally spelt as Puriwidji), there is one principle to hold on-namely TUHSIRAPPUH, a four-syllable acronym, which means (1) TUH (wutuh) is complete or without decays (corrosion); SI (wesi) is the material (steel, iron, and meteor); RAP (garap) is design of Kris, Lok, Pamor etc., finally PUH (Sepuh) is the period of production-ancient (Sepuh) belonging to Singasari and Majapahit eras, moderate (Mataraman) belonging to eras of Islamic Kingdoms, and modern (Kamardikan) produced, after Indonesian Independence in 1945.

\section{Materials and manufacturing process}

The basic materials for Kris manufacturing include (1) steel, (2) iron and (3) meteor for the Pamor or Patterns on the blades. However, due to the fact that meteorite stone is now rarely found, nickel is used as a substitute for meteor. These three materials have different metal boiling points but they can be unified in forging processes, which is termed as 'saton' meaning 'unity'. Thus, it is the unity of three materials, and in the ancient time may refer to the unity of God's Powers: Brahma, Wisnu, and Syiwa.

The manufacturing of a Kris is performed by an expert called Empu which originally means "the one who possesses (special skills). In English, several words, such as blacksmith, metalsmith, blade smith to name only a few may represent the conceptual meaning of an Empu. Most distinctively, a Kris Empu has to be differentiated from a common blacksmith. An Empu must possess special knowledge, technical skills, and also prowess since the final product (Kris) is believed to have mystical or magical power, depending on the goal.

During the forging process, an Empu may pronounce or recite he mantra to fill the saton with magical power. In modern time, however, the saton may 
EduLite Journal of English Education, Literature, and Culture

not consist of the three types of materials as above. Other materials, such as brass and or copper may be used as a substitute. Therefore, despite the form is similar to Kris, it is actually not a Kris. In order to be called 'Kris', no other materials can replace the original saton. It is argued that the blade (a Kris) is made in layers of different iron ores and meteorite nickel. It can be made in a relatively short time, while a more intricate Kris takes years to complete. In high quality kris blades, the metal is folded dozens or hundreds of times and handled with the utmost precision. Thus, Empu are highly respected craftsmen with additional knowledge in literature, history, and the occult.

Nowadays, modern equipment is used to complete the production of Kris, which cannot be assumed to be the past practice, which was all traditionally performed. it was / is very complex to produce just one mystical Kris viewed from technical and spiritual entities. Viewed from kris manufacturing processes, it is therefore factual that ancient Kris is simple while modern Kris also called Kamardikan Kris (produced after Indonesian Independence in 1945). Kamardikan Kris is very beautiful with a lot of ornaments. Such a Kris is good as souvenir, from common souvenir up to Presidential Souvenir-a souvenir exchange between two heads of state.

\section{Selected legendary Krises: Philosophical and symbolic values}

Described below are 10 legendary Kris(es) with interesting philosophical and symbolic values as historical manifestations as revealed in the interviews.

(1) Keris Kyai Sengkelat

a. A Kris with 13 curves (Lok 13);

b. The name Sengkelat means las-lasaning urip (the ultimate end of life), ambiguously implying 'bringing life to an end (kill) without failure or the unity of human and God (death);

c. Made in the era of King Prabu Kertabumi Brawijaya V of Majapahit by a metalsmith, Mpu Supa Mandagri, who is the student of Sunan Ampel.

d. Made from pointed cis stone, normally used to drive camels, it was found by Sunan Ampel when praying to God., believed to belong to Prophet Muhammad SAW.

e. Sunan ordered Mpu Supa to make a sword from it but the Empu made it into a Kris Lok 13 and named it Kyai Sengkelat.

f. When submitted to Sunan, he was disappointed because Kris is related to Hinduism. He wanted a sword-in line with Arabic culture, the origin of Islam.

g. Sunan ordered that the Kris be submitted to King Brawijaya V. In fact, the King was happy with it and made it the mascot of the Kingdom, and also named it Kanjeng kyai Ageng Puwara.

h. The Kris was kept in a special room;

i. Nowadays, there are many replicas of this Kris

(2) Keris Pusaka Kalamunyeng

a. A straight Kris

b. Kalam (Arabic: Qalam) means a pen, while munyeng means going around and around in the air (like a war-plane). 
c. Legendarily told that King Brawijaya was angry with Sunan Giri's Spiritual School, considered to challenge Majapahit Kingdom (endangered sovereignty)

d. The troops were led by Prime Minister Gajah Mada. Giri people rushed to the house of Sunan Giri.

e. At that time, Sunan Giri was writing (with a pen).

f. He was surprised, he then threw his pen at the troops. On God's wish, the pen changed into a Kris and killed all the soldiers.

g. Another interpretation of Kalamunyeng is that at that time, Sunan Giri was thinking hard how to defend himself and his people from the attack. His pen was cursed to be a Kris, and then flew around killing the soldiers.

(3) Keris Tamingsari

a. A three-curve Kris (Keris Lok 3)

b. Made from 99 different kinds of iron and Elixir of moringa wood belonging to a powerful fighter named Tamingsari from Majapahit, who was defeated by Hang Tuah.

c. Alexis (galih) of moringa wood has a magical power to drive away evil spirits.

(4) Keris Kyai Carubuk

a. A seven-curve Kris (Keris Lok 7)

b. The concept of Carubuk is that humans must behave like the earth to powerfully accommodate what is expected and not expected and to support righteous deeds.

c. Sunan Kalijaga ordered Mpu Supa Mandragi to make a kris which would be used to slaughter goats.

d. Sunan gave a small piece of iron (as small as a fruit seed)

e. Mpu Supa was surprised to receive the small piece of irondespite being small in size, it was very heavy in weight.

f. At first, Mpu supa was not sure that the iron could be forced to make a Kris; but tapi Sunan convinced that despite being small in size, it is actually as gigantic as a mount. When Sunan pronounced the word 'a mount', the iron turned to be a big piece of iron-as the size of a mount. Mpu Supa kneeled down in with fears.

g. Finally, a Kris was made. Upon submission, Sunan was surprised because it was not like what he expected. It was very beautiful. The the Kris was awarded to King Sultan Hadiwijaya, King of Pajang, who was named Jaka Tingkir when he was young.

(5) Keris Nagasasra Sabukinten

a. A 13-curve Kris (Keris Lok 13)

b. In reign of King Prabu Brawijaya V, there was a difficult period of time due to foreign expansion, pandemic, and natural disasters.

c. The King ordered Mpu Supa a Kris which could normalize the chaotic situation, bringing peace to the people of Majapahit

d. Mpu Supa performed a 40-day meditation to locate meteorite stone as the material to make a Kris. 
e. A 13-curve Kris with an ornament of a dragon's head nicely ornamented or adorned with diamonds from the neck to the tip of the Kris.

f. The Kris became the mascot of Majapahit Kingdom

(6) Keris Kyai Condong Campur

a. A straight Kris

b. Condhong means "to tend, or to side'; while campur means 'to mix'

c. The Kris was meant for unity of differences.

d. It was narrated that the Kris was made in collaboration of 100 Empus and the materials were taken from various places. The Kris was very powerful but with evil spirits.

e. Keris sabuk inten attacked this Kris without success. However, Kris Kyai Condong Catur was defeated by Keris Sengkelat.

f. This Kris then flew to the sky and turned into a tailed star (Lintang Kemukus) and threatened that it would come down every 500 ... to create chaotic situations (disasters).

(7) Keris Pusaka Bangas Setan Kober

a. A 13-curve Kris

b. Belonging to Arya Penangsang, the Regent of Jipan Panolan

c. Product of Mpu Supa, Tuban East Java, the student of Sunan Ampel.

d. Made from Bangas Rock

e. The Kris is of Hot Aura (Spirit) as it would not stop until the fall of its enemies

f. The Kris was finally destroyed upon the death of the owner, Arya Penangsang, killed by Danang Sutawijaya using a Sword Kyai Plered

(8) Keris Empu Gandring

a. The name was taken after its maker, Mpu Gandring; of Malang East Java. The Empu had not even named it.

b. It was narrated that Ken Arok ordered Mpu Gandring to make a Kris to kill Tunggul Ametung, King Tumapel, who was magically powerful. By rumor, King Tumapel never laughed so that it was assumed that his weakness was in his throat inside the mouth.

c. Ken Arok was getting angry because it took a long time to finalize the Kris. Ken Arok by force took the Kris and used it to kill the Empu.

d. While he was dying, Mpu Gandring cursed that the Kris shall kill seven Kings of Singasari including Ken Arok (king of Singasari) and his offspring.

e. However, a new historical analysis was indicated that Ken Ken Arok killed Empu Gandring politically to hide the maker of this powerful Kris.

f. To avoid further assassinations, the Kris was thrown into a mount crater. Other legend said it was swallowed by a powerful female fighter.

(9) Keris Kanjeng Kyai Ageng Gopek

a. This keris is the Prime Heirloom of Yogyakarta Kingdom. 
Purwanto, S., \& Nuhamidah, I. (2021). Introduction to Kris, a traditional weapon of Indonesia:

b. This kris cannot be separated from Sultan in power of Yogyakarta Kingdom.

c. Keris Kanjeng Kyai Ageng Kopek ini symbolizes that Sultan is the Spiritual Head for life here and after.

(10) Kanjeng Kyai Joko Piturun

a. This Pusaka (Kris) is the second rank in the world of Kris within Yogyakarta Kingdom

b. Joko means a single male and Piturin

c. Kanjeng Kyai Joko Piturun would be awarded to the Prince, the then King of Yogyakarta Kingdom.

d. It was narrated that this Kris used to belong to Sunan Kalijaga, and it was made by a famous blade-smith form Demak Kingdom.

Some of the names above have become standards or prototypes (including the number of curves) called 'Dhapur'. Therefore, we have Dhapur Sengkelat, Dhapur Nogososro, Dhapur Sabuk Inten. etc.

It is important to note that a Kris is labelled according to its legendary functions and power. The highest level is Kanjeng Kyai, for example Keris Kanjeng Kyai Ageng Gopek, followed by a lower level, Kyai, as in Keris Kyai Condong Campur, then Keris Pusaka (heirloom) as in Keris Pusakan Bangas Setan Kober and finally just Keris, as in Keris Empu Gandring.

\section{CONCLUSION}

Kris is Indonesia's oral and intangible heritage of humanity that has to be well preserved as the national identity of Nusantara (Indonesia) to represent the people and their intellectual and civilization development. It has been recognized by UNESCO as one of the highest intellectual property, thereby becoming national pride of Indonesia. Kris can be viewed in terms of aesthetics and magics. For those who believe, Kris has special merits depending on period of production (Tangguh), process of production or styles, designs (Garap) and the patterns (Pamor) on its blade with of course the blade (Wilah) itself. In addition, Kris can also represent the owner's ways of life. It is therefore recommended that a program called "one person-at least one Kris" be put in a cultural policy. If it works, there will more than 200 million Kris(es) throughout the Indonesian Archipelago. It is really ironical that Kris is well-known all over the world but only partly known by Indonesian people. 
Edulite Journal of English Education, Literature, and Culture

\section{REFERENCES}

Aji, M. T. C., Suryani, N., \& Musadad, A. A. (2019). Religious cultural Arts in mentality system of Javanese society: A critical analysis to the dynamics of 'Keris' development as a religious archaelogy. EduLite: Journal of English Education, Literature and Culture, 4(2), 247-260. https://doi.org/10.30659/e.4.2.247-260

Coenen, J., Bager, S., Meyfroidt, P., Newig, J., \& Challies, E. (2021). Environmental Governance of China's Belt and Road Initiative. Environmental Policy and Governance, 31(1), 3-17. https://doi.org/10.1002/eet.1901

Erdal, G., \& Gucuyener, I. (2021). The knife of Bursa in Turkish culture: A historical and cultural study. African Journal of History and Culture, 13(1), 19-26. https://doi.org/10.5897/AJHC2020.0493

Fatmawati, D. (2021). Islam and Local Wisdom in Indonesia. Journal of Social Science, 2(1), 20-28. https://doi.org/10.46799/jsss.v2i1.82

Frey, E. (2003). The Kris mystic weapon of the Malay world. ITBM.

Groneman, I. (2009). The Javanese Kris (O. Niessen, Sandra A.; Oosterbeek (ed.); 1st ed.). C. Zwartenkot Art Books - Leiden and KI $\square$ LV Press. https://www.academia.edu/23350430/THE_JAVANESE_KRIS

Handriyotopo, H., \& Simatupang, L. L. (2018). Keris Symbols in The Emblem and Brand Logo. Bandung Creative Movement (BCM) Journal, 4(1). https://openlibrarypublications.telkomuniversity.ac.id/index.php/bcm/article/ view $/ 5873$

Julianto, T., Setiawan, R., \& Harianja, R. F. (2021). Local-Social Wisdom in the Nyadran Tradition as a Means of Gathering. Budapest International Research and Critics in Linguistics and Education (BirLE) Journal, 4(2), 830-836. https://doi.org/10.33258/birle.v4i2.1862

Peng, T., \& Deng, H. (2021). Evaluating urban resource and environment carrying capacity by using an innovative indicator system based on eco-civilization-a case study of Guiyang. Environmental Science and Pollution Research, 28(6), 6941-6955. https://doi.org/10.1007/s11356-020-11020-7

Pidada, A. (2021). Army System of The Battles in Bali in The Physical Revolution of The Nica 1945-1950. KULTURISTIK: Jurnal Bahasa Dan Budaya, 5(1), 43-50. https://doi.org/10.22225/kulturistik.5.1.2681

Rahman, J. A. (2020). Exploring the sketches of hulu keris (dagger hilt) of master craftsman Norhaiza Noordin. Design Ideals Journal, 2(2). https://journals.iium.edu.my/kaed/index.php/dij/article/view/601

Rukachaisirikul, T., Kumjun, S., Suebsakwong, P., Apiratikul, N., \& Suksamrarn, A. (2021). A new pyrrole alkaloid from the roots of Cissampelos pareira. Natural Product

Research, 35(1), 80-87. https://doi.org/10.1080/14786419.2019.1614576

Sutrisno, M. (2018). A Technical Discourse: The Making of Pendhok Kris in Surakarta Style. Wacana Seni Journal of Arts Discourse, 17, 107-137. https://web.b.ebscohost.com/abstract?direct=true\&profile=ehost\&scope=site\&a uthtype $=$ crawler\&jrnl $=16753410 \& A N=134457274 \% \mathrm{~h}=$ qtNkOVUjg9K3XpUKH3azx JPSnwyLXkys1UOtAZ4TnFj\%2Fr8blb5BQYVz9F\%2B3CRNBfXBgHjgDhoqzFDrn2 NqLaRA\%3D\%3D\&crl=c\&resultNs=AdminWebAuth\&resultLocal=ErrCrlNotAuth\& crlhashurl=login.aspx\%3Fdirect\%3Dtrue\%26profile\%3Dehost\%26scope\%3Dsite \%26authtype\%3Dcrawler\%26jrnl\%3D16753410\%26AN\%3D134457274 
Purwanto, S., \& Nuhamidah, I. (2021). Introduction to Kris, a traditional weapon of Indonesia:

Preserved-lingering issues of facts. EduLite: Journal of English Education, Literature, and Culture, 6 (2), 397 410. http://dx.doi.org/10.30659/e.6.2.397-410

van Huis, A. (2021). Cultural Significance of Beetles in Sub-Saharan Africa. Insects, 12(4), 368. https://doi.org/10.3390/insects12040368

Wijayanto, E. (2019). Keris as a culture text: Hermeneutics review of Pusaka Keris Magazine. International Review of Humanities Studies, 4(1), 299-312. https://doi.org/https://dx.doi.org/10.7454/irhs.v4i1.143

Wu, M., Liu, Y., Xu, Z., Yan, G., Ma, M., Zhou, S., \& Qian, Y. (2021). Spatio-temporal dynamics of China's ecological civilization progress after implementing national conservation strategy. Journal of Cleaner Production, 285, 124886. https://doi.org/10.1016/j.jclepro.2020.124886

Zvejniece, L., Dambrova, M., \& Smits, G. (2021). Total synthesis and in vivo evaluation of 8-deoxypumiliotoxin 193H. Natural Product Research, 35(3), 440-446. https://doi.org/10.1080/14786419.2019.1636244

Conflict of Interest Statement: The authors declare that the research was conducted in the absence of any commercial or financial relationships that could be construed as a potential conflict of interest.

Copyright (c) 2021 Purwanto and Nurhamidah. This is an open-access article distributed under the terms of the Creative Commons Attribution License (CC BY). The use, distribution or reproduction in other forums is permitted, provided the original author(s) and the copyright owner(s) are credited and that the original publication in this journal is cited, in accordance with accepted academic practice. No use, distribution or reproduction is permitted which does not comply with these terms. 